\title{
Nonbioequivalent prescription drug interchangeability, concerns on patient safety and drug market dynamics in Brazil
}

\author{
Intercambialidade de medicamentos não-bioequivalentes, \\ segurança do paciente e dinâmica do mercado farmacêutico \\ no Brasil
}

Francisco José Roma Paumgartten ${ }^{1}$

Ana Cecilia Amado Xavier de Oliveira ${ }^{1}$

' Escola Nacional de Saúde Pública, Fiocruz. Av. Brasil 4036/913, Manguinhos.

21040-361 Rio de Janeiro RJ Brasil.

paum@ensp.fiocruz.br

\begin{abstract}
Since the enforcement of Generics Act (1999), three types of pharmaceutically equivalent products are marketed in Brazil: innovative reference (REF), "similar" $(S)$ and generic $(G)$ drugs. The $S$ (brand name) and $G$ (generic name) borrow from REF (brand name) clinical data on safety and efficacy and dosage regimen. $G$ (but not $S$ ) is bioequivalent to and interchangeable with REF. Starting in 2003, Brazilian Sanitary Surveillance Agency (Anvisa) has required data on relative bioavailability tests (with REF) to approve (or renew registration of) $S$ drugs. In 2014, Anvisa extended interchangeability notion to similar drugs with a "comparable" bioavailability, i.e., an "equivalent" similar drug (EQ). Drugs for chronic diseases and "critical dose medicines" are listed among the EQ drugs approved. Interchangeability of nonbioequivalent medicines raises deep concerns regarding therapeutic failures and adverse events. Concerns are even more worrisome if patients switch from one drug to another during an ongoing treatment for illnesses such as epilepsy, congestive heart failure, hypertension, diabetes and/or substitutable drugs have a narrow therapeutic index.
\end{abstract}

Key words Generics, Drugs, Therapeutic equivalence, Legislation
Resumo A partir da vigência da lei dos genéricos (1999), três tipos de produtos farmaceuticamente equivalentes são comercializados no Brasil: o medicamento inovador de refência (REF), o produto "similar" (S), e o genérico $(G)$. O similar (nome de fantasia) e o genérico (nome genérico) tomam de empréstimo do REF (nome de fantasia) os dados clínicos de segurança e eficácia e a posologia. $G$ (mas não S) é bioequivalente ao, e intercambiável com REF. Desde 2003, a Agência Nacional de Vigilância Sanitária (Anvisa) exige dados de testes de biodisponibilidade relativa para registrar (ou renovar o registro de) medicamentos S. Em 2014, a Anvisa estendeu o conceito de intercambialidade aos medicamentos similares com biodisponibilidade "comparável", i.e., um medicamento similar "equivalente" (EQ). Medicamentos para doenças crônicas e "fármacos de dose crítica" estão listados entre os produtos EQ aprovados. A intercambialidade de medicamentos não-bioequivalentes suscita grande preocupação quanto a falhas terapêuticas e eventos adversos. Os receios são ainda maiores se os pacientes trocam um medicamento por outro durante o tratamento de doenças como epilepsia, insuficiência cardíaca, hipertensão, diabetes elou os produtos farmacêuticos substituídos tem um indice terapêutico estreito.

Palavras-chave Medicamentos genéricos, Produtos farmacêuticos, Equivalência terapêutica, Legislação 


\section{Introduction}

In Brazil, patients often find on the pharmacy shelves four distinct types of products containing the same active ingredient of the medicine specified on their prescription. That is, a "reference" drug identified by a brand name, its "similar" and "equivalent" drugs (identified by brand names as well) and the corresponding generic drugs (labelled by the active ingredient generic name). The packing of "generic" drugs bears a yellow band with the "G" symbol. All "equivalent" drugs are listed on the list of interchangeable similar drugs published (and periodically updated) by the Brazilian Sanitary Surveillance Agency (Anvisa), and their package insert information contain a statement saying that they are equivalent to a reference medicine ("Similar drug equivalent to the reference drug") ${ }^{1}$. If patients have a valid prescription for a reference drug, pharmacists may offer them the generic (G) and/or equivalent (EQ) medicines that can substitute the one specified on the prescription. Nonetheless, if doctors specified either a $G$ or an EQ drug on the prescription, pharmacists should warn patients that these drugs can only be substituted by the corresponding reference medications. In other words, while a reference medicine can be replaced with either its $\mathrm{G}$ or EQ drugs, and vice versa, $\mathrm{G}$ and EQ products are not interchangeable with each other. Figure 1 shows a diagram illustrating the Brazilian rules for pharmaceutical interchangeability or substitutability.

The scientific rationale behind the foregoing rules for pharmaceutical interchangeability resides on two distinct yet closely related pharmacokinetic notions, bioequivalence and relative bioavailability.

In this article, we examined the Brazil's current regulation for prescription drug substitutability in light of the concepts of drug bioavailability, relative bioavailability and bioequivalence. Addressing this topic, we highlighted the risks posed by making nonbioequivalent pharmaceutical products interchangeable, particularly when drugs have a narrow therapeutic index and are prescribed for chronic medical conditions such as convulsive disorders, congestive heart failure, cancer and others.

\section{Methods}

This article describes, explains and critically appraises the rules for prescription drug inter- changeability or substitutability introduced by the Brazilian Sanitary Surveillance authority (Anvisa). The authors, at the outset, undertook a thorough literature search to identify references relevant to the drug regulation topic addressed in the paper. Biomedical literature electronic databases (Medline/Pubmed, BVS Brazil/Bireme (http://www.brasil.bvs.br) and the Virtual Library on Health of the Brazilian Ministry of Health (BVS MS, www.bvsms.saude.gov.br/index.php) were searched covering a time windown between the inception of the database and Sept 25,2016 . Depending on the database, the search was conducted using a variety of searching terms in English (e.g., "generics AND bioequivalence", "generics AND interchangeability", "generics substitution", "generics legislation", drug intercangeability", "guidance and bioequivalence", "drug switchability" and others) and/or corresponding terms in Portuguese (BVS-MS, BVS Brazil/Bireme). Moreover, authors went over an updated version (updated on Sept 19, 2016) of a Brazilian Sanitary Surveillance Agency (Anvisa)'s compilation of legislation on health products to identify all regulations and laws applicable to this drug regulatory topic ${ }^{2}$. The literature search was aimed to select documents and articles relevant to address questions such as "What are the current Brazilian rules for drug interchangeability or substitutability of prescription drugs at the pharmacies?", "Is there a scientific rationale for making drug products with 'comparable' bioavailability, although not being proven bioequivalent products, interchangeable with each other?", "Are the concerns regarding generic drug substitution justified?"

A note on terminology. Dictionaries (e.g. Merriam-Webster Dictionary) give very similar definitions for English terms (adjectives) substitutable and interchangeable. Substitutable means "capable of being exchanged for another or for something else that is equivalent" (as a substitute, or valid as a replacement) while interchangeable means "capable of being interchanged", or something that is freely substitutable or swapped at will. As far as drug therapy is concerned, these terms have been used analogously to express more or less the same notion, or have been employed to refer to subtly different things. For instance, in clinical practice therapeutic interchangeability could mean that prescribers can switch one drug for another medicine within the same therapeutic class, or from distinct therapeutic classes but with a similar pharmacological effect and potency. Along the same line, therapeutic substitution is the exchange of a drug for a disctinct, yet phar- 

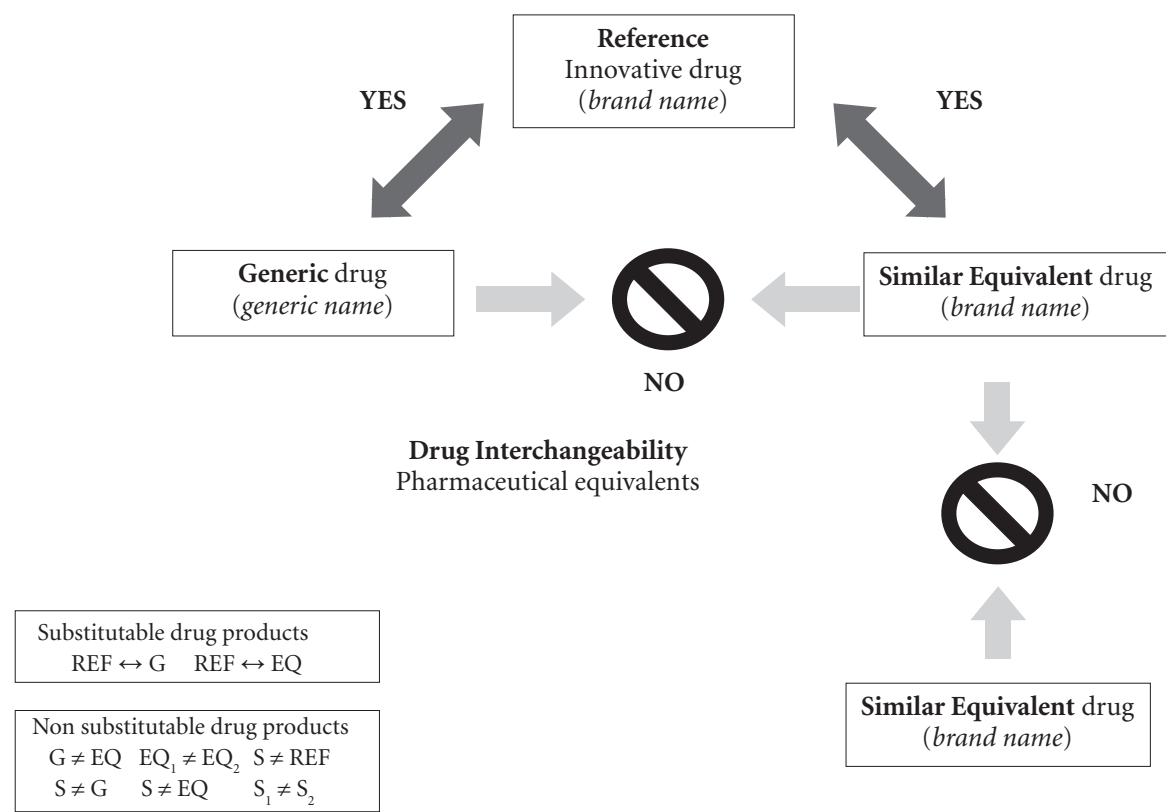

Figure 1. The Brazilian rules for pharmaceutical interchangeability or substitutability. Innovative reference drugs (REF) are interchangeable with either a proven bioequivalent generic drug $(G)$ or a similar equivalent drug (EQ) with a "comparable" bioavailability. G and EQ drugs, however, are not interchangeable with each other, nor are interchangeable two EQ products or two similar (S) drugs containing the same active compound. REF, S, G and EQ are pharmaceutically equivalent products, yet not necessarily bioequivalent or therapeutically equivalent drug products. $\leftrightarrow$ : drugs substitutable for each other; $\neq$ : drugs non substitutable for each other.

maceutically equivalent product, when the pharmacist dispenses it without prior authorization of the initial prescriber. The corresponding adjectives in Portuguese (intercambiável, substituível, e.g. "Dicionário Houaiss da língua portuguesa") convey essentially the same meaning (capable of being exchanged or that are replaceable with each other) and are more often than not employed as synonyms. Throughout this article, the English terms drug interchangeability (interchangeable) and drug substitutability (substitutable) are used to express the same concept.

\section{Results and discussion}

\section{Bioavailability, relative bioavailability and bioequivalence}

Drug bioavailability - or absolute bioavailability - refers to the fraction of an administered dose of a drug (unchanged) that reaches the intravascular compartment, i.e., the systemic circulation. If a drug is injected directly into the intravascular compartment (e.g., by intravenous injection, iv), the absorption phase and a possible pre-systemic clearance are circumvented so that it is fair to assume that after iv administration the drug bioavailability is $100 \%$. Owing to incomplete absorption and first-pass metabolism - which depend on a number of variables, and may vary from patient to patient - bioavailability after administration by extravascular routes, including the oral route - is generally less than $100 \%$. The term bioavailability may also refer to a measurement of the rate and degree to which a pharmacologically active compound reaches its site of action in the organism. The absolute bioavailability is determined by comparing the area under the plasma concentration versus time curve (AUC) of a drug after application by one extravascular route (usually the oral route) with the AUC obtained after iv injection of the same molar dose $\mathrm{e}^{3,4}$. That is, for oral administration of drug " $D$ " the bioavailability or fraction absorbed (F) is: 
$\mathrm{F}(\mathrm{D})=\mathrm{AUC}_{0-\infty}(\mathrm{D})$ oral $/ \mathrm{AUC}_{0-\infty}(\mathrm{D})$ iv

If the oral AUC is equal to the iv AUC (i.e., $\mathrm{F}$ $=1$ ) it is fair to assume that the drug is completely absorbed after oral administration. In most cases, however, $\mathrm{F}<1$.

Likewise absolute bioavailability $(\mathrm{F})$, relative bioavailability is also a ratio of AUCs. In the latter case, however, it is the ratio of AUC for one formulation of the active compound to the AUC calculated for a distinct formulation of the compound, provided AUCs were obtained for the same molar dose of a drug given through the same route of administration. That is, "relative bioavailability" refers to a ratio of bioavailability (AUCs) between two distinct products containing the same active ingredient, such as a comparison of bioavailability between two similar medicines, or between a "reference" drug and one of its "similar" drugs $s^{3,4}$.

If the bioavailability (i.e., the rate and extent of availability) of an active ingredient common to two distinct pharmaceutical products is nearly the same, whenever the drugs are given in the same molar dose and through the same route of administration (e.g., oral route), the two drug products are considered as being bioequivalent. It is expected that two bioequivalent drug formulations have comparable in vivo performances and, therefore, share a common optimized dose regimen and an identical clinical efficacy and safety profile $e^{5,6}$.

\section{Reference, similar, similar equivalent and generic drugs}

A reference innovative drug contains at least one pharmacologically active ingredient that is, or was, under patent by a research \& development pharmaceutical company. To achieve an innovative drug marketing approval, sponsors have to provide data from a comprehensive set of nonclinical and clinical studies demonstrating that it is effective and safe for the proposed therapeutic indications. The optimized dosage regimen for the reference drug (informed in package inserts to guide prescribers and patients) relies on the empiric evidence arising from clinical trials conducted by the pharmaceutical company. The manufacturer's proposal on the usual dosage regimen and dose adjustments is part of a new drug application for marketing authorization.

A similar drug $(S)$ is a product pharmaceutically equivalent to an innovative reference drug. Drugs are pharmaceutical equivalents if they contain the same active ingredient, are of the same dosage form (e.g., tablet, capsule, solution, ointment, cream, etc), are equal in strength or concentration (i.e., have a same amount of active ingredient in the dosage form, or dose unit) and are given by the same route of administration. Although being pharmaceutical equivalents, similar and reference innovative drugs are not proven bioequivalent products. Notwithstanding this fact, a similar drug borrows from its reference innovative drug the non-clinical and clinical demonstration of efficacy and safety and the recommended dosage regimen.

Until 2003, there was virtually no information on the bioavailability of most similar drugs marketed in the country. Prescribers were then unaware of the degree to which bioavailability of similar drugs deviated from that of the reference drug previously tested in clinical trials. The Resolutions RDC n. 133 and RDC n.134, issued by the Brazilian Sanitary Surveillance Agency (Anvisa) on May 29, 2003, however, introduced a set of more stringent criteria for registration of similar drugs among which a requirement for data on relative bioavailability tests (i.e., the similar medicine tested against the reference product $)^{7,8}$. In 2014, Anvisa issued a regulation (RDC 58/2014, Art. 2) stating that similar drug products are potentially interchangeable with a reference medicine, pending the analysis by the agency of results of pharmaceutical equivalence and relative bioavailability/bioequivalence studies, or if sponsors demonstrate that they are to be classified among those types of drugs that are exempted from these studies ${ }^{1}$. Still according to RDC 58/2014, package insert of interchangeable similar drugs (EQ) shall contain information on the interchangeability. Moreover, RDC 58/2014 says that Anvisa is committed to updating a list of interchangeable similar drug products and respective reference drugs on its website ${ }^{1}$.

The Technical Regulation for Similar Drugs (RDC 133/2003) allows the sponsor to alter the formulation of a similar drug to make its kinetic parameters $\left(\mathrm{C}_{\max }, \mathrm{AUC}\right.$, and $\left.\mathrm{T}_{\max }\right)$ compatible with those of the reference drug . If sponsors choose not to do so, they must propose an alternative dosage regimen as to ensure the attainment of active ingredient plasma levels consistently above the minimum therapeutic level and below the toxic level. Whether or not sponsor-produced adjustments in a similar drug product formulation succeeded in making it interchangeable with a reference product depends on a case-by-case evaluation and decision by the agency. 
Some changes in a similar drug formulation and manufacturing process other than a mere alteration in the concentration of the active ingredient, such as modifying excipients and pharmaco-technical properties (thickness, hardness, friability, disintegration, drug particle size, and others), can make it bioequivalent to another pharmaceutical product. Nonetheless, if AUC and/or other kinetic parameters - of similar and reference drugs become comparable at expenses of changes in the active ingredient concentration or drug unit, similar and corresponding reference drugs cannot be considered as bioequivalent drug products. Moreover, if concentration of a similar drug dosage form (dose unit) is altered, the similar and its corresponding reference drug would no longer be pharmaceutical equivalent products.

A generic drug is by definition (Federal Act $9.787 / 1999)$ a pharmaceutical product "..similar to a reference or innovative product, which intends to be interchangeable with it, generally produced after the expiration or waiver of the patent protection or of any other rights of exclusiveness, upon verification of its effectiveness, safety and quality, and designated by the CBD (Common Brazilian Denomination) or, in its absence, by the INN (International Nonproprietary Name)". Except for types of drugs exempt from bioequivalence study, and some particular cases for which pharmaceutical equivalence tests may replace in vivo bioequivalence assays, the demonstration that a generic drug is in fact interchangeable with the corresponding reference drug product requires a clinical bioequivalence study ${ }^{9}$. In other words, $\mathrm{G}$ and the corresponding reference drug are not only pharmaceutically equivalent but also therapeutically equivalent products for which one could expect a same optimized dosage regimen, efficacy and safety.

\section{Logical inference chain is not applicable to drug interchangeability rules}

A logical inference chain would say; if $\mathrm{A}$ is equal to $B$ and $B$ is equal to $C$, then $C$ is equal to A. As shown in Figure 1 diagram, a logical inference chain does not hold true for drug interchangeability rules adopted in Brazil. The reason why a logical inference chain is not applicable to drug substitutability rules is because G, EQ and the corresponding reference drug are not identical pharmaceutical products regarding rate and extent of bioavailability, even if they are considered as therapeutically comparable (REF vs EQ) or sufficiently bioequivalent (REF vs $G$ ) to a same reference drug product.

It is of note that a bioequivalence assay is typically a two-treatment crossover study design involving a limited number of adult volunteers ( 24 to 36) who receive single oral doses of a test drug and its reference product ${ }^{4,6,10}$. The kinetic parameters related to the extent (i.e., $\mathrm{AUC}_{0-\mathrm{t}}$ up to the last measure, and $\mathrm{AUC}_{0-\infty}$ extrapolated to infinity) and the rate $\left(\mathrm{C}_{\max }\right.$ and $\left.\mathrm{T}_{\max }\right)$ of bioavailability are determined for both drug products. According to Anvisa's Guide for drug relative bioavailability/bioequivalence tests (RE no 1170/2006) ${ }^{10}$ two pharmaceutical products are bioequivalent if the upper and lower limits of $90 \%$ Confidence Intervals (CIs) determined for geometric means of AUCs ([AUC ${ }_{0-\mathrm{t}}$-test drug] / $\left[\mathrm{AUC}_{0-\mathrm{t}}-\mathrm{REF}\right]$ ) and $\mathrm{C}_{\max }\left(\left[\mathrm{C}_{\max }\right.\right.$-test drug $\left.] /\left[\mathrm{C}_{\max }-\mathrm{REF}\right]\right)$ ratios are greater than 0.8 and smaller than 1.25. If "time to peak concentration" $\left(\mathrm{T}_{\max }\right)$ is a clinically relevant parameter for a particular medication, eventual discrepancies in $\mathrm{T}_{\max }$ values should also be considered before concluding that two drugs are bioequivalent. The foregoing bioequivalence criteria for registration of generic drugs in Brazil are consistent with international guidelines and criteria adopted in the US Food and Drug Administration (FDA), Canada (Health Canada), Europe (European Medicines Agency -EMA) and Australia ${ }^{11,12}$.

The primary concern underpinning regulatory rigorous criteria for drug bioequivalence is to ensure that patients are protected against approval of generic products that are not bioequivalent and, consequently, not safely interchangeable with a reference drug. As aforementioned, the conclusion that two products are (or are not) bioequivalent stands on a statistical criterion, i.e., 90\% CI for ratios of peak plasma concentrations $\left(\mathrm{C}_{\max }\right)$ and plasma concentration-time curves areas $\left(\mathrm{AUC}_{0-\mathrm{t}}\right)$ must lie entirely between $80(0.8)$ and $125 \%$ (1.25) boundaries. This calculation and numerical index provide an indication of the certainty of conclusions based on bioequivalence test results. It is of note that the width of the $90 \%$ CI reflects to some degree the within-subject variability in the test and the product variability. In principle, a test product that does not differ from the REF might eventually fail to pass bioequivalence study criteria if variability of one or both products is high and the study involves a small number of volunteers (i.e., the test has insufficient statistical power $)^{4,6,10,12}$. It is also possible that a test drug with a low variability passes the bioequivalence test even if the test drug and 
REF product exhibit large differences in the average response of pharmacokinetic parameters. Notwithstanding these possibilities, one can say, taking into account the test design and statistical criteria, that there is no more than a $5 \%$ chance that an approved G drug is not truly bioequivalent to a REF drug product.

Nonetheless, as noted by Peterson ${ }^{13}$, the criterion adopted for bioequivalence has been misinterpreted as implying that "bioavailability $\left(\mathrm{C}_{\max }\right.$ and AUCs) must be within the range of $80-125 \%$ of the reference product"13,14. This misinterpretation may lead to unfounded concerns that interchangeability between REF and G drugs might endanger patients' health, a self-serving myth promoted by the so-called "innovative" pharmaceutical industry. Actually, as demonstrated by Birkett ${ }^{5}$, differences in $\mathrm{C}_{\text {max }}$ and AUC values of $\mathrm{G}$ and REF drugs must generally be less than $10 \%$ to satisfy the $90 \%$ CI bioequivalence requirement. In practice, Birkett's estimation is confirmed by a survey of 127 bioequivalence studies submitted to US FDA (applications approved in 1997) which revealed that the observed average differences $( \pm$ $\mathrm{SD}$ ) between $\mathrm{G}$ and REF drugs in $\mathrm{C}_{\max }, \mathrm{AUC}_{0-\mathrm{t}}$, and $\mathrm{AUC}_{0-\infty}$ were $\pm 3.47 \%( \pm 2.84), \pm 3.25 \%( \pm$ $2.97)$ and $\pm 4.29 \%$ ( \pm 3.72$)$, respectively ${ }^{15}$.

One of the reasons why a logical inference chain is by no means applicable to drug interchangeability rules is because while $G$ is sufficiently bioequivalent to REF, bioequivalence between EQ and REF remains unproven. Nonetheless, even if a bioequivalent test shows that EQ is bioequivalent to REF, one could not reach the conclusion (based on the statistical criteria for bioequivalence) that $\mathrm{EQ}$ is bioequivalent to $G$, unless one undertakes an additional test comparing directly $G$ against EQ. Moreover, tests (bioequivalence and relative bioavailability) and criteria that lead Anvisa to conclude that $\mathrm{G}$ is interchangeable with REF are distinct from those that indicate that bioavailability of EQ and REF are sufficiently "comparable" to make them interchangeable with each other.

\section{Risks of making non-bioequivalent drug products interchangeable}

Notwithstanding the rigorous testing and regulatory criteria to assure bioequivalence, some physicians and patient organizations have questioned whether it would be safe to switch from a REF to a $G$ drug (and vice versa) in the case of medicines with a narrow therapeutic index (or critical dose medicines). This would hold particularly true for patients who are under treatment for chronic medical conditions such as epilepsy, hypertension, diabetes, congestive heart failure, cancer, and others ${ }^{16-22}$. In principle, relatively small variations in plasma concentrations of critical dose medicines, such as antiepileptic drugs (carbamazepine, phenytoin, gabapentin, lamotrigine, sodium valproate, and others), digoxin, lithium, cyclosporine, warfarin, and others, may cause adverse effects or loss of efficacy. However, it is unclear whether there is in fact a significant risk from REF substitution with $G$ drugs in all cases of critical dose medicines. For instance, although there are reports that substitution of anti-epileptic drugs in certain individuals may be problematic leading to breakthrough seizures $^{16-19}$, a systematic review by Yamada and Welty ${ }^{23}$ reached the conclusion that the strongest levels of evidence available suggested that $G$ antiepileptic drug substitution was not problematic. Moreover, a number of studies, systematic reviews and meta-analyses do not lend to notion that switching from brandname to generic medicines might result in loss or worsened control of disease symptoms ${ }^{24-26}$.

Owing to the fact that EQ and REF drugs are not proven bioequivalent products, substitution of REF by EQ raises justifiable concerns regarding potential adverse health outcomes. Along this line, the main issue of concern regarding interchangeability is not so much on the dosage regimen (which EQ borrowed from REF) of an initial therapy to achieve the same health outcome, but, rather, on the eventual switching from one drug to another during an ongoing treatment for a chronic condition. In a patient individual basis, variations in active ingredient plasma levels due to switching from one product to another may result in the disease control failure or drug adverse events. The extension of substitutability concept to nonbioequivalent EQ drugs (introduced by Anvisa's RDC 58/2014) ${ }^{1}$ not only loosened safety standards for drug interchangeability but also, what is worse, overlooked the marked health risks posed by switching critical dose drug products which are not bioequivalent.

As shown in Chart 1, Anvisa's list of similar EQ drug products interchangeable with innovative reference branded drugs includes a number of medications for chronic medical conditions and critical dose medicines. 
Chart 1. Pharmacologically active ingredients of similar equivalent drugs (EQ) for chronic medical conditions (some of which are critical dose medicines) listed by ANVISA among those similar drugs interchangeable with brand-name reference drugs (REF). From a list updated on ANVISA website on August 31, 2016.

(http://portal.anvisa.gov.br/documents/33836/352782/Lista+de+medicamentos+similares+intercambi\%C3\%A1 veis/27d0f06c-5082-4a92-a667-08b4763a498f)

\begin{tabular}{|l|l|}
\hline \multicolumn{1}{|c|}{ Drug therapeutic class } & \multicolumn{1}{|c|}{ Active ingredient } \\
\hline Anticoagulant drugs & sodium warfarin \\
\hline Antidepressant drugs & $\begin{array}{l}\text { amitriptyline, citalopram, venlafaxine, escitalopram, } \\
\text { lithium carbonate }\end{array}$ \\
\hline Antidiabetic drugs & metformin, pioglitazone, glimepriride \\
\hline Antiepileptic / anticonvulsant drugs & $\begin{array}{l}\text { gabapentin, valproic acid, sodium valproate, phenytoin, } \\
\text { carbamazepine, lamotrigine, topiramate, phenobarbital }\end{array}$ \\
\hline Antihyperlipidemic drugs (statins) & atorvastatin, rosuvastatin, simvastatin \\
\hline $\begin{array}{l}\text { Antihypertensive drugs } \\
\text { Angiotensin converting enzyme (ACE) inhibitors }\end{array}$ & $\begin{array}{l}\text { captopril, enalapril, ramipril } \\
\text { irbesartan }\end{array}$ \\
\hline \multicolumn{1}{|c|}{ Angiotensin II receptor antagonists } & $\begin{array}{l}\text { olanzapine, haloperidol, risperidone, clozapine, } \\
\text { chlorpromazine }\end{array}$ \\
\hline Antipsychotic drugs & $\begin{array}{l}\text { digoxin } \\
\text { colchicine }\end{array}$ \\
\hline Cardiac glycosides & $\begin{array}{l}\text { docetaxel, etoposide, imanitib, carboplatin, methotrexate, } \\
\text { bortezomid }\end{array}$ \\
\hline Gout treatment & Oncologic drugs
\end{tabular}

Chart 2. Bioequivalence with innovative reference drug and other disctinctive characteristcs of prescription drugs marketed in Brazil.

\begin{tabular}{|c|c|c|c|c|}
\hline Drug product & $\begin{array}{c}\text { Innovative reference } \\
\text { drug (REF) }\end{array}$ & Generic drug $(G)$ & $\begin{array}{c}\text { Similar equivalent } \\
\text { drug (EQ) }\end{array}$ & Similar drug (S) \\
\hline \multicolumn{5}{|l|}{ Labeling } \\
\hline Name & Brand-name & Generic name & Brand-name & Brand-name \\
\hline $\begin{array}{l}\text { Indication on the } \\
\text { external packing }\end{array}$ & No & $\begin{array}{c}\text { Yellow band - G } \\
\text { symbol }\end{array}$ & No & No \\
\hline \multicolumn{5}{|c|}{ Efficacy and Safety (proof) } \\
\hline Nonclinical studies & Required & Not required & Not required & Not required \\
\hline Clinical studies & Required & Not required & Not required & Not required \\
\hline Interchangeability & $\mathrm{EQ}, \mathrm{G}$ & REF, G & REF & $\underline{\text { Not }} \underline{\underline{\text { intercheangeable }}}$ \\
\hline Pharmacy sale prices & Reference & $\begin{array}{l}\text { Cheaper } \\
\text { (at least } 35 \% \text { lower- } \\
\text { than REF) }\end{array}$ & No price limit & $\underline{\text { No price limit }}$ \\
\hline $\begin{array}{l}\text { Pharmaceutical } \\
\text { equivalence }\end{array}$ & Reference & $\begin{array}{c}\text { Pharmaceutical } \\
\text { equivalent }\end{array}$ & $\begin{array}{c}\text { Pharmaceutical } \\
\text { equivalent }\end{array}$ & $\begin{array}{c}\text { Pharmaceutical } \\
\text { equivalent }\end{array}$ \\
\hline $\begin{array}{l}\text { Bioequivalence } \\
\text { (proof) }\end{array}$ & Reference & Proven bioequivalent & Not required & Not required \\
\hline $\begin{array}{l}\text { "Comparable" } \\
\text { bioavailability yet not } \\
\text { proven bioequivalent }\end{array}$ & Reference & Proven bioequivalent & $\begin{array}{l}\text { "Comparable" } \\
\text { bioavailability }\end{array}$ & 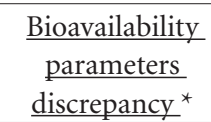 \\
\hline
\end{tabular}

* Based on the outcome of relative bioavailability tests, a dosage regimen adjustment may be required so that drug plasma levels are kept above the minimum therapeutic levels and below the maximum non-toxic levels (RDC 133/2003). 


\section{Changes in drug interchangeability rules, moving forward, backward and sideways}

The so-called "similar" drugs are a uniqueness of Brazilian pharmaceutical market. According to the former Brazilian Patent Act promulgated on December 21 ${ }^{\text {st }}, 1971$ (Federal Act 5772/1971)27 drugs and pharmaceutical ingredients could not be patented in the country. Owing to this fact, the basic sanitary surveillance law (Act 6360/1976) ${ }^{28}$ authorized registration and sales of drugs that shared with an innovative drug a same active ingredient, that is, "similar" drugs. Since 1996, a new patent law recognized patent rights over certain products and innovative ideas including drugs. In 1999, Brazil's Congress passed the Generic drug Act (Act 9787/1999) ${ }^{9}$ amending the Sanitary Surveillance Act (Act 6360/1976) ${ }^{28}$. The Generics Act stated that all similar drugs and their innovative reference drugs must be labelled with brand names, while $G$ drugs must be designated by their generic names, and be bioequivalent and therapeutically interchangeable with REF drugs.

As previously commented, RDC58/2014 made similar equivalent drugs (EQ), an unproven bioequivalent product, interchangeable with REF drugs. Apparently, agency's decision to loosen safety standards for drug interchangeability aimed to increase the number of alternatives to innovative branded drugs thereby forcing down prices of prescription drugs. Initially, Brazilian health authorities (Ministry of Health and Director of Anvisa) announced that, likewise generics packing requirements, external packing of similar equivalent drugs would bear a yellow band and a large EQ symbol ensuring a prompt recognition by potential consumers, and in addition to that would have to be cheaper than the reference drug $^{29,30}$. Facing a strong criticism by pharmaceutical companies, health authorities stepped back in relation to both requirements ${ }^{31,32}$. As summarized in Chart 2 for the two types of drugs potentially interchangeable with a reference drug, $G$ drugs have to be bioequivalent, identified by a generic name, and sold at lower prices, while EQ drugs are not proven bioequivalent drugs, and have brand names and no price limit. Celebrated by some politicians and authorities as a Columbus' egg idea to lower prescription drug prices,
RDC 58/2014 ${ }^{1}$ was in fact a clumsy regulatory intervention on the drug market that brought more confusion than clarity and certainly loosened country's regulatory standards for patient safety protection. The long-term impact of RDC $58 / 2014$ on the development of generics market and prescription drug-pricing dynamics in Brazil, however, remain largely unclear.

\section{Concluding remarks}

A major safety concern about the interchangeability of medicines is whether or not, and the extent to which dosage regimens established with basis on clinical trials of an innovative drug are valid for a pharmaceutically equivalent yet distinct formulation of the same active ingredient produced by another manufacturer.

Theoretically, even relatively small variations in drug bioavailability (rate and extent) and plasma levels arising from differences in product formulation and/or manufacturing process might lead to therapeutic failure or adverse events when a test drug borrows the dosage regimen from its innovative reference medicine. Along this line, one generally agrees upon that if a test drug and its reference drug are sufficiently bioequivalent products, they are potentially interchangeable medicines.

In Brazil, a new rule for drug interchangeability introduced in $2014(\mathrm{RDC} 58 / 2014)^{1}$ extended substitutability (adopted for generic drugs since 1999) to a novel category of pharmaceutical products, i.e., the so-called "similar equivalent" drugs for which therapeutic equivalence is accepted based on "comparable" bioavailability determined in relative bioavailability tests.

It is of note that Anvisa's requirement for data on relative bioavailability of similar drugs introduced in 2003 (until then there was virtually no data on the rate and extent of bioavailability of most similar medicines) was a step forward to making the use of medicines safer and more effective in the country. The extension of interchangeability concept to unproven bioequivalent drug products, however, is a serious step backwards as regards the promotion and protection of patient safety. 


\section{Collaborations}

FJR Paumgartten and ACAX Oliveira jointly conceived the main ideas discussed in the article and are equally responsible for its conclusions. ACAX Oliveira and FJR Paumgartten reviewed the literature and FJR Paumgartten elaborated a first draft of the manuscript. Both authors critically reviewed successive drafts of the paper and approved the final version to be published.

\section{References}

1. Brasil. Ministério da Saúde (MS). Agência Nacional de Vigilância Sanitária - Anvisa. Resolution RDC 58/2014. Deals with agency's requirements for deciding that a similar drug is interchangeable with its reference medicine. [cited 2016 Sept 27]. Available at: http://bvsms. saude.gov.br/bvs/saudelegis/anvisa/2014/rdc0058 _10_10_2014.pdf

2. Brasil. Ministério da Saúde (MS). Agência Nacional de Vigilância Sanitária - Anvisa. Estoque Regulatório da Anvisa. [Consolidado_Estoque_Regulatório_Portal.xlsx - Excel; updated on Sept 19, 2016]. [cited 2016 Sept 27]. Available at: http://www.portal.anvisa.gov.br/legislacao

3. Midha KK, Gordon McKay G. Bioequivalence; Its History, Practice, and Future. AAPS J 2009; 11(4):664-670.

4. United States Food and Drug Administration (US FDA). Guidance for Industry. Statistical Approaches to Establishing Bioequivalence. 2001. 48 p. [cited 2016 Sept 7]. Available at: http://www.fda.gov/downloads/ Drugs/.../Guidances/ucm070244.pdf

5. Birkett DJ. Generics - equal or not? Aust Prescr 2003; 26:85-87.

6. European Medicines Agency (EMA). Guideline on the investigation of bioequivalence. 2010, 27 p. [cited Sept 6, 2016]. Available at: http://www.ema. europa. eu/ docs/en_GB/document_library/Scientific_ guideline/ 2010/01/ WC500070039. pdf

7. Brasil. Ministério da Saúde (MS). Agência Nacional de Vigilância Sanitária - Anvisa. Resolution RDC 133/2003. Deals with agency's requirements for similar drug registration in Brazil. [cited 2016 Sept 6]. Available at: http:// www.anvisa.gov.br/medicamentos/legis/resol.htm

8. Brasil. Ministério da Saúde (MS). Agência Nacional de Vigilância Sanitária - Anvisa. Resolution RDC 134/2004. Deals with agency's requirements for introducing changes in the formulation and manufacturing process of registered medicines. [cited Sept 6, 2016.]. Available at: http://www.anvisa.gov.br/medicamentos/ legis/resol.htm

9. Brasil. Federal Act 9787/1999. Generics Act [cited Sept 12, 2016]. Available at: http:// http://www.anvisa.gov. $\mathrm{br} /$ medicamentos/ legis/resol.htm

10. Brasil. Ministério da Saúde (MS). Agência Nacional de Vigilância Sanitária - Anvisa. Resolution RE 1170/2006. Guide for drug relative bioavailability/bioequivalence tests. [cited Sept 18, 2016]. Available at: http://www.lex. com.br/doc_839912_ RESOLUCAO_1170_ DE_19_ DE_ABRIL_DE_2006.aspx

11. Davit B, Braddy AC, Conner DP, Yu LX. International guidelines for bioequivalence of systemically available orally administered generic drug products: a survey of similarities and differences. AAPS J 2013; 15(4):974990.

12. Galgatte UC, Jamdade VR, Aute PP, Chaudhari PD. Study on requirements of bioequivalence for registration of pharmaceutical products in USA, Europe and Canada. Saudi Pharm J 2014; 22(5):391-402.

13. Peterson GM. Generic substitution: a need for clarification. Br J Clin Pharmacol 2011; 71(6):966-967.

14. Duerden MG, Hughes DA. Generic and therapeutic substitutions in the UK: are they a good thing? Br J Clin Pharmacol 2010; 70(3):335-341.

15. Henney JE. From the Food and Drug Administration. Review of generic bioequivalence studies. JAMA 1999; 282(21):1995 
16. Berg MJ, Gross RA, Tomaszewski KJ, Zingaro WM, Haskins LS. Generic substitution in the treatment of epilepsy: case evidence of breakthrough seizures. Neurology 2008; 71(7):525-530.

17. Privitera MD. Generic antiepileptic drugs: current controversies and future directions. Epilepsy Curr 2008; 8(5):113-117.

18. Peterson GM. Generic substitution of antiepileptics: need for a balanced view. CNS Spectr 2011;16(8):169175.

19. Borgherini G. The bioequivalence and therapeutic efficacy of generic versus brand-name psychoactive drugs. Clinical Therapeutics 2003; 25(6):1578-1592.

20. Gidal BE, Tomson T. Debate: Substitution of generic drugs in epilepsy: is there cause for concern? Epilepsia 2008; 49(Supl. 9):56-62.

21. Bialer M. Generic products of antiepileptic drugs (AEDs): is it an issue? Epilepsia 2007; 48(10):18251832.

22. Soinska-Schneider A. Reservation notes against generic substitution - solely medical considerations? [thesis]. Oslo: University of Oslo; 2011.

23. Yamada M, Welty TE. Generic substitution of antiepileptic drugs: a systematic review of prospective and retrospective studies. Ann Pharmacother 2011; 45(11):1406-1415

24. Corrao G, Soranna D, Arfe A, Casula M, Tragni E, Merlino L, Mancia G, Catapano AL. Are generic and brandname statins clinically equivalent? Evidence from a real data-base. Eur J Intern Med 2014; 25(8):745-750.

25. Kesselheim AS, Misono AS, Lee JL, Stedman MR, Brookhart MA, Choudhry NK, Shrank WH. Clinical equivalence of generic and brand-name drugs used in cardiovascular disease: a systematic review and meta-analysis. JAMA 2008; 300(21):2514-2526.

26. Godman B, Bennie M, Baumgärtel, Sovic-Brkičić L, Burkhardt T, Fürst J, Garuoliene K, Gomes M, Markovic-Pekovic V, Martin A, Sermet C, Skiold P, van Woerkom M, Voncina L, Gustafsson LL. Essential to increase the use of generics in Europe to maintain comprehensive health care? Farmacoeconomia.Health Economics and therapeutic pathways 2012; 13(Supl. 3):5-20.

27. Brasil. Federal Act 5772/1971. Industrial Property Code. [cited Sept 12, 2016]. Available at: http://www.lexml. gov.br/urn/urn:lex:br:federal:lei:1971-12-21;5772
28. Brasil. Lei no 6.360, de 23 de setembro de 1976. Dispõe sobre a Vigilância Sanitária a que ficam sujeitos os Medicamentos, as Drogas, os Insumos Farmacêuticos e Correlatos, Cosméticos, Saneantes e Outros Produtos, e dá outras Providências. [Federal Act 6.360/1976. Deals with sanitary surveillance of medicines, pharmaceutical ingredients, cosmetics, disinfectants and other products]. Diário Oficial da União 1976; 24 set. [cited Sept 6, 2016]. Available at: http://www.planalto.gov.br/ ccivil_03/leis/L6360.htm

29. Brasil. Ministério da Saúde (MS). Blog da Saúde. Serviços. Brasileiros terão mais opções na compra de medicamentos. Published on 16/01/2014. [cited 2016 Sep 28]. Available at: http://www.blog.saude.gov.br/servicos/33508-brasileiros-terao-mais-opcoes-na-compra-de-medicamentos.html

30. Mendes P. Bem Estar - Medicamento similar deve passar por testes de equivalência, propõe Anvisa. G1.Portal da Globo.com Published on 16/01/2014. [cited 2016 Sep 28]. Available at: http://g1.globo.com/bemestar/ noticia/2014/01/medicamento-similar-deve-passar -por-testes-de-equivalencia-propoe-anvisa.html

31. Conselho Regional de Farmácia de São Paulo (CRF -SP). Notícias. Atenção Farmacêuticos. Publicada RDC que estabelece regras para intercambialidade de medicamentos similares com os de referência. Published on 14/10/2014. [cited 2016 Sep 28]. Available at: http:// portal.crfsp.org.br/index.php/noticias/5890-nova-regra.html

32. Formenti L. Anvisa muda regras para compra de medicamento similar. Estadão conteúdo. Estado de São Paulo. [Internet] Published on 9/10/2014. [cited 2016 Sep 28]. Available at: http://www.estadao.com.br/noticias/ geral,anvisa-muda-regra-para-compra-de-medicamento-similar,1574316

Artigo apresentado em 24/10/2016

Aprovado em 10/04/2017

Versão final apresentada em 12/04/2017 